Katarzyna Woźniak

Uniwersytet Wrocławski

Wydział Filologiczny

Instytut Filologii Romańskiej

https://doi.org/10.18778/8220-478-0.14

\title{
TEATR LUDOWY PRL JAKO PRZEDMIOT BADAŃ KOMPARATYSTYCZNYCH ZARYS PROBLEMATYKI
}

Streszczenie: Komparatystyczne, polsko-włoskie podejście do teatru ludowego PRL wymaga od badacza przede wszystkim zdefiniowania charakteru zbiorowości, jaką jego twórcy określali mianem "ludu” nie tyle ze względu na wieloznaczność samego pojęcia „ludu”, co na dodatkową trudność wynikającą z faktu, że określenie teatro popolare skłania, w sposób bardziej bezpośredni niż w języku polskim, do szukania powinowactw z projektem Jeana Vilara. Dookreślenie, w odniesieniu do Konstytucji PRL, terminu "lud pracujący” i przeciwstawienie go narodowi, otwiera przed badaczem szersze ramy interpretacyjne dynamiki, w jakiej kształtował się projekt kulturalny teatru ludowego PRL, a w szczególności Teatru Ludowego Krystyny Skuszanki-Krasowskiej, Jerzego Krasowskiego i Józefa Szajny.

Słowa klucze: teatr ludowy, teatr powszechny, teatro popolare, teatro per il popolo, komparatystyka teatru

Abstract: La definizione del "teatro popolare" rappresenta una sfida per gli studi comparati italo-polacchi di teatro. Infatti, analizzando la situazione istituzionale del teatro polacco e quello italiano degli anni Sessanta e Settanta, la prima sfida è quella di tradurre il termine "ludowy" in italiano: si tratta di un teatro "per il popolo" nello stesso significato del "popolo" che ne dava la Repubblica Popolare Polacca? In altre parole, cercando la risposta a questa domanda, dobbiamo chiederci, come "sperimentavano" la popolarità / "ludowość" gli ambienti teatrali e istituzionali italiani e polacchi del secondo dopoguerra.

Parole chiave: teatro popolare, teatro per il popolo, studi comparativi del teatro 
Eugenio Barba opowiada ${ }^{1}$, że w trakcie swojego pobytu w Polsce nawiązała się między nim a Krystyną Skuszanką i jej mężem, Jerzym Krasowskim, głęboka przyjaźń. Barba był młodym adeptem reżyserii, oni stosunkowo niedawno objęli dyrekcję (Skuszanka) i kierownictwo artystyczne (Krasowski) Teatru Ludowego w Nowej Hucie. W tym czasie Skuszanka, jako reżyserka, często sięgała po włoski repertuar. $\mathrm{W}$ pierwszych sezonach nowo otwartej sceny razem z Jerzym Krasowskim wyreżyserowała Księżniczkę Turandot Carla Gozziego (1956), a samodzielnie Stugę dwóch panów Carla Goldoniego (1957). Wybory te są o tyle istotne, o ile - jak pisze Aleksandra Koman - można je uznać za faktyczny początek nowohuckiego teatru².

Skuszanka była znana i ceniona we Włoszech jako artystka eksperymentująca $\mathrm{z}$ formą. Lamberto Trezzini, autor pierwszego - i jak dotąd jedynego - włoskiego, monograficznego opracowania historii polskiego teatru, wydanego w 1962 roku odnotował, że kierowana przez nią scena wymyka się łatwym klasyfikacjom. W latach pięćdziesiątych Trezzini był krytykiem teatralnym i sprawnym organizatorem. Tak wówczas, jak w późniejszym okresie, interesowały go przede wszystkim zagadnienia organizacji produkcji teatralnej (między innymi będzie kierownikiem pierwszych studiów wyższych poświęconych temu zagadnieniu, utworzonych w 1971 roku na Uniwersytecie Bolońskim). Przebywał w Polsce na przełomie lat pięćdziesiątych i sześćdziesiątych i opisywał polską rzeczywistość teatralną z własnego doświadczenia. Choć na płaszczyźnie faktograficznej jego wywód dotyczący Skuszanki należałoby traktować ostrożnie (nie brak w nim bowiem uproszczeń właściwych tego rodzaju panoramicznym ujęciom, ale i przekłamań - Trezzini nazywa Skuszankę „założycielką” (fondatrice) Teatru Ludowego - a jego uwagi o „spontanicznej naturze" kierowanej przez nią sceny brzmią co najmniej naiwnie), trudno jednak odmówić mu racji, gdy pisze, że z włoskiej perspektywy nowohucki teatr trudno nazwać ludowym ${ }^{3}$. Zresztą sama Skuszanka głośno wyrażała wątpli-

1 E. Barba, Ziemia popiołu i diamentów. Moje terminowanie w Polsce oraz 26 listów Jerzego Grotowskiego do Eugenia Barby, Wrocław 2001, s. 19-20.

2 W okresie PRL w Teatrze Ludowym wystawiono: Księżniczkę Turandot Carla Gozziego (1956, reż. Krystyna Skuszanka, Jerzy Krasowski), Stugę dwóch panów Carla Goldoniego (1957, reż. Krystyna Skuszanka), Bliźniaki z Wenecji (1967, reż. Bogdan Hussakowski), Mirandolinę (1969, reż. Irena Babel), Awanturę w Chioggi (1981, reż. Jerzy Ronald Bujański), Cyrulikia Sewilskiego Gioachina Rossiniego (1973, reż. Waldemar Krygier), Raj Alberta Moravii (1983, reż. Zbigniew Samogranicki). Obszerna analiza włoskiego repertuaru w Teatrze Ludowym zob. rozprawę doktorską Aleksandry Koman (w trakcie przygotowania), poświęconą teatralnym interpretacjom literatury włoskiej na krakowskich scenach po październiku 1956.

3 L. Trezzini, Teatro in Polonia, Bologna 1962, s. 148. 
wości co do nazwy kierowanej przez siebie sceny. W sezonie inaugurującym działalność Teatru Ludowego mówiła:

Nie wiem, czy najlepiej się stało, że nowej placówce teatralnej w Nowej Hucie nadano nazwę „Teatru Ludowego" [...]. Istnieje jeszcze tendencja „ludowego" jako peryferii kultury, często „sztuka ludowa” staje się synonimem folkloru, szerzej zaś i bardziej historycznie tłumaczona bywa jako nurt plebejski w kulturze ${ }^{4}$.

Trezzini ceni polską reżyserkę za to, że zrezygnowała z akademickiej konwencji inscenizacji klasyków - jak w przypadku pokazywanego w Wenecji w 1957 roku Stugi dwóch panów - i dostrzega w jej pracy antykonformistyczne dążenie do urzeczywistniania teatru, który we Włoszech przyjęło się nazywać teatrem powszechnym 5 .

Obok małżeństwa Krasowskich, istotną postacią pierwszego okresu działalności Teatru Ludowego był Józef Szajna - najpierw jako scenograf i współinscenizator przedstawień Skuszanki, a następnie dyrektor nowohuckiej sceny (od 1963 do 1966 roku). To z ich wizji zrodził się nowatorski teatr, z powodzeniem konkurujący z najważniejszymi scenami Krakowa ${ }^{6}$.

Tematem niniejszego tekstu jest nieprzystawalność włoskiego określenia popolare do kulturalnego projektu Krasowskich i Szajny ${ }^{7}$, zasadzającego się na teatrze. W pierwszej części pokazuję wątpliwości Trezziniego w kontekście powszechnie przyjętych definicji teatru ludowego i teatru powszechnego (théâtre populaire), w drugiej zaś proponuję poszerzenie tych definicji o rozumienie „ludu” za Konstytucją Polskiej Rzeczpospolitej Ludowej z 22 lipca 1952 roku. Robię to w przekonaniu, że dopiero uzupełniając te definicje o prawną interpretację terminu „lud” w kontekście PRL można budować przekonywujące

4 K. Skuszanka, Teatr na straży młodości, [w:] „Dziennik Polski” 1955, nr 3569, s. 8 .

5 L. Trezzini, op. cit., s. 150-151.

6 D. Domański, Teatr noszę w sobie [w: ],Gazeta Krakowska” 2005, 289, www.eteatr.pl/pl/artykuly/19600,druk.html [dostęp: 31.03.2020] * Po latach wspominał: „[Teatr Ludowy] był w jakimś sensie przeciwwagą, ale uważam, że wówczas Stary Teatr w Krakowie był bardzo stary, tak z nazwy, jak i z treści. My tworzyliśmy w Nowej Hucie młody teatr. Stary Teatr miał raczej bulwarowy charakter, grano w nim Krowoderskie zuchy czy Moralność pani Dulskiej, zaś Teatr im. Słowackiego był wielką trumną historii, pustą, gdzie obok Lope de Vegi wystawiano np. Tragedię optymistyczną. Najbardziej z krakowskich scen zaznaczała się Groteska, wnosząc nowy powiew sztuki m.in. dzięki plastykom".

7 Jego częścią był, między innymi, Klub Dyskusyjny (od 1962 Koło Miłośników Teatru Ludowego). 
narracje komparatystyczne na temat projektu kulturalnego Teatru Ludowego w latach 1955-1966. Ze względu na rozmiar tekstu, ograniczam się przy tym wyłącznie do zarysowania ram metodologicznych dla mojej refleksjii.

Warto w tym miejscu dodać, że o ile najbardziej rozpoznawalnymi polskimi twórcami teatralnymi we Włoszech pozostają do dzisiaj Jerzy Grotowski i Tadeusz Kantor, o tyle propozycje Skuszanki, formułowane na przełomie lat pięćdziesiątych i sześćdziesiątych, mogły budzić zainteresowanie włoskich artystów, szukających nowych, inkluzyjnych modeli teatru. Choćby z tego względu recepcja jej twórczości w tym środowisku zasługuje na szersze opracowanie.

\section{Popolare, czyli ludowy, powszechny, uniwersalny, demokratyczny}

Problemy z przeprowadzeniem typologii polskich scen z włoskiej perspektywy widać wyraźnie w terminologii stosowanej przez Trezziniego. Dla przykładu: autor przekłada nazwę „teatr powszechny” jako „universale”, por. Teatro universale a Varsavia - Teatr Powszechny w Warszawie; z kolei w przypadku Krakowa o Teatrze im. J. Słowackiego pisze: Teatro distato „Stowacki” - Teatr Państwowy im. J. Słowackiego - jednocześnie pomijając fakt, że także Stary Teatr od 1956 roku był teatrem państwowym - Teatro „Modrzejewska” a Cracovia. Można z tego wywnioskować, że Trezzini, zdaje się, też nie do końca rozumiał uwarunkowania prawne i kontekst instytucjonalny, w jakim działały polskie sceny.

Choć określenie „teatr ludowy” w przypadku nowohuckiej sceny budzi wątpliwości autora, Trezzini nie poszukuje jednak bardziej adekwatnego włoskiego ekwiwalentu tej nazwy. Skupia się natomiast na artystycznym wymiarze pracy zespołu Skuszanki i usilnie wyszukuje argumenty na obronę tezy, że teatr awangardowy - za jaki niewątpliwie uważa teatr polskiej reżyserki - może być jednocześnie teatrem ludowym. Fascynacja działalnością Skuszanki skłania go nawet do sformułowania bardzo radykalnego stanowiska: „na dzień dzisiejszy - pisał - Teatr Ludowy jest być może jedynym w Europie prawdziwie ludowym teatrem eksperymentalnym”. Broniąc „teatru ludowego", starał się pogodzić dwie, tradycyjnie przeciwstawiane sobie koncepcje teatru: ludowość i innowacyjność. Podsumowując stwierdza, że propozycja Teatru Ludowego to „wyjątkowe i pozytywne zjawisko odnowy kulturalnej polskich mas robot-

8 Badania są częścią projektu poświęconego recepcji Krystyny Skuszanki we Włoszech oraz jej zainteresowań repertuarem włoskim i kontaktom z włoskim środowiskiem artystycznym. W ramach projektu, obok książki poświęconej tym zagadnieniom, powstaje wspomniana już rozprawa doktorska Aleksandry Koman.

9 L. Trezzini, op. cit., s. 150-151 (Tłumaczenie własne). 
niczych - to teatr zasadzający się na najwyższych wartościach ludzkich i sztuce rozumianej jako edukacja i moralność” 10 .

Z czego mogą wynikać wątpliwości Trezziniego co do ludowego charakteru nowohuckiej sceny, a co nie zostaje powiedziane w jego książce wprost? Po pierwsze $\mathrm{z}$ faktu, iż w kręgu kultur romańskich teatro popolare - a takie właśnie, dosłowne tłumaczenie nazwy zaproponował Trezzini dla Teatru Ludowego - przywodzi od razu na myśl bardzo nośną w owym czasie koncepcję théâtre populaire Jeana Vilara, założyciela Théâtre National Populaire (1951), którego nazwę na język polski przyjęło się tłumaczyć jako Narodowy Teatr Powszechny - a nie - „ludowy” ${ }^{11}$. Jasnym jest zatem, że w polskim kontekście kulturowym nazwa Teatr Ludowy nie wywołuje wprost tego rodzaju skojarzeń, jakie z pewnością musiały nasuwać się włoskiemu autorowi. Teatr Vilara miał sięgać po najwybitniejsze dzieła rodzimej i światowej klasyki i przybliżać je niezamożnej publiczności. Łączył więc aspekt artystyczny z misją społeczną, a nawet służbą, bo tak rozumiał swoje zadanie jego twórca. Jeśli przyjąć, że teatr ludowy to „ogólna i różnorodnie rozumiana kategoria przedstawień teatralnych przeznaczonych dla „ludu” - najuboższej ludności miejskiej i wiejskiej, uznawanej za przeciwieństwo widzów wykształconych i wyposażonych w odpowiednie dla odbioru teatru kompetencje kulturowe"12, można uznać Théâtre National Populaire za jedną z jego form, a sam teatr ludowy za kategorię o wiele bardziej pojemną.

Po drugie, w słownikach języka włoskiego znajdujemy następujące podstawowe znaczenia popolare: ludowy, gdzie lud jest rozumiany jako zbiorowość obywateli, bez względu na przynależność klasową, a zatem i powszechny; ludowy jako przynależny ogółowi niższych klas społecznych, ubogich, a zatem zacofanych gospodarczo, ekonomicznie i społecznie; w końcu „ludowy” jako atrybut sztuki, która wywodzi się z tradycji, z kultury ludu ${ }^{13}$. W niektórych natrafimy ponadto na ciekawe $\mathrm{w}$ kontekście prowadzonych $\mathrm{w}$ tym miejscu rozważań odwołanie do demokratycznego charakteru governo popolare, czyli

10 Ibidem, (Tłumaczenie własne).

11 Por. J. Legoń, Jean Vilar, [w:] „Encyklopedia Teatru Polskiego”, www. encyklopediateatru.pl/osoby/52132/jean-vilar [dostęp: 30.03.2020].

12 Por. D. Ratajczakowa, Teatr ludowy, [w: ] Encyklopedia Teatru Polskiego”, www.encyklopediateatru.pl/hasla/163/teatr-ludowy [dostęp: 30.03.2020].

13 „popolare”[w:],"Treccani”,www.treccani.it/vocabolario/popolare1/[30.03.2020]: "Del popolo, inteso come collettività dei cittadini, senza distinzione di classi sociali [...], Che si riferisce al popolo inteso come insieme delle classi sociali meno elevate, aventi un tenore di vita modesto, e quindi economicamente, socialmente, culturalmente arretrate $[\ldots]$; di espressione, forme d'arte e simili che trae origine dalle tradizioni, dalla cultura del popolo”; „Grande Dizionario Italiano” Hoepli, www.grandidizionari.it/Dizionario Italiano/parola/P/popolare_1.aspx?query=popolare+(1) [dostęp: 30.03.2020]. 
władzy ludu zapewne rozumianego raczej w duchu Deklaracji praw człowieka i obywatela niż Deklaracji praw ludu pracującego i wyzyskiwanego. Tak dochodzimy do kluczowej dla kwestii podstaw ideologicznych definicji ludu ${ }^{14}$.

Opisując język, jakim się posługujemy, opisujemy także ludzkie poznanie. Stwierdzenie to, fundamentalne dla Langackerowskiego kognitywizmu, trafnie oddaje naturę podstawowego problemu badań porównawczych zjawisk „teatrów dla mas" w szerokim znaczeniu teatrów ukształtowanych na przesłankach ideologicznych i przeznaczonych dla dużych grup odbiorców. Jak podkreślają autorzy antologii tekstów poświęconych polskim teatrom dla masowej publiczności w międzywojniu, teatr ludowy, „mimo postulatów powszechności [...] zawsze był projektem politycznym i to $\mathrm{w}$ najbardziej radykalnej odmianie. Był projektem dydaktycznym, a nawet perswazyjnym"15. Ustanawiając teatr ludowy PRL jako przedmiot badań komparatystycznych, a w szczególności interesujący mnie nowohucki Teatr Ludowy, wypada zatem odpowiedzieć na pytanie, o jakiej publiczności myśleli jego fundator, czyli Ministerstwo Kultury i Sztuki PRL, a dopiero w następnej kolejności o jakiej publiczności myślała Skuszanka. Nie jest bowiem tajemnicą, że rozbieżności wizji dyrektor i władz były przedmiotem sporów i prasowych polemik. To właśnie w tym dynamicznym dialogu kształtowała się „tożsamość” nowo powołanej sceny.

\section{Lud, czyli „ludzie żyjący z pracy społecznie użytecznej i nie wyzyskujący innych" 16}

Jak wynika z artykułu Władysława Zamkowskiego Pojęcie ludu pracujacego w Konstytucji PRL, opublikowanego na łamach „Ruchu Prawniczego, Ekonomicznego i Socjologicznego" w 1965 roku, terminu „lud” używano w języku prawnym PRL podobnie jak w mowie potocznej, to znaczy „dla nazwania społeczności wiejskiej (lud wiejski, stąd też pochodzą nazwy stronnictw chłopskich, np. Zjednoczone Stronnictwo Ludowe, określenia: pieśni ludowe, tańce ludowe). Przymiotnik «ludowy» zbliżony jest oprócz tego swoim znaczeniem pojęciowym do terminu «powszechny»"17. Rozumienie „ludowości” w języku prawnym nie odbiegało zatem od jego znaczenia słownikowego, ale

14 „popolare” [w:] „Grande Dizionario Italiano” Hoepli, www.grandidizionari. it/Dizionario_Italiano/parola/P/popolare_1.aspx?query=popolare+(1) [dostęp: 30.03.2020]: "democratico; governo popolare, a cui partecipa il popolo; sovranità popolare, che è nelle mani del popolo, dei suoi rappresentanti”.

15 P. Olkusz, M. Wąsik (red.), Teatry dla masowej publiczności, Łódź 2017, s. 12.

16 W. Zamkowski, Pojęcie ludu pracującego w Konstytucji PRL, „Ruch Prawniczy, Ekonomiczny i Socjologiczny” 1965, 27 z. 2, s. 35.

17 Ibidem., s. 26-27. 
to nie lud w ogóle interesował autorów Konstytucji PRL. Ponieważ „Polska Rzeczpospolita Ludowa jest republiką ludu pracującego" ${ }^{18}$, Zamkowski uznaje za konieczne doprecyzować, jaką zbiorowość miał na myśli ustawodawca, a robi to, by powszechnie uświadomiono sobie „wię[ź], która łączy przygniatającą większość [społeczeństwa PRL] w lud pracujący miast i wsi”"19, do czego jeszcze powrócę w kontekście zadań teatru ludowego PRL. Podsumowując swoje rozważania, autor definiuje lud pracujący jako „wspólnotę ludzi żyjących z pracy społecznie użytecznej i nie wyzyskujących innych, zorganizowanych w państwo" 20 .

Istotne jest także przeprowadzone przez Zamkowskiego rozróżnienie między narodem i ludem, a mianowicie stwierdzenie, że narodu nie można utożsamiać z ludem pracującym, ponieważ „zbieżność interesów tych obu wspólnot społecznych, tak wyraźnie występująca w praktyce i akcentowana w Konstytucji, nie może prowadzić - zdaniem autora - do utożsamiania zbiorowości społecznej zwanej ludem pracującym i wspólnoty narodowej”21. Idąc tym tropem, teatru ludowego PRL nie można by utożsamiać z teatrem narodowym, gdyż na tle Konstytucji PRL „lud pracujący i naród stanowią odrębne formy zbiorowego życia ludzi" ${ }^{22}$. Mimo iż między narodem - choćby ze względu na to, że należą do niego „pozostałości klas wyzyskujących”23 - a ludem w 1965 roku nie można było postawić znaku równości ${ }^{24}$, w ocenie autora w przyszłości sytuacja ta mogłaby się zmienić, „W miarę postępujących przeobrażeń ekonomiczno-społecznych i ujednolicenia społeczeństwa w tym sensie, że wszyscy stają się ludźmi pracy"25. Aby tak się stało, więź, o której wspomniałam wcześniej, musi zostać uświadomiona, bowiem:

nie zawsze jest rozumiana i doceniana przez ludzi pracy. Nad więzami solidarności, które mogłyby powstać na podstawie wspólnych interesów i dążeń politycznych, dominują inne - narodowe, religijne, państwowe, celowo przeciwstawiane przez klasy panujące więzom solidarności pracujących. Trzeba

18 Wszystkie cytaty za: Konstytucja Polskiej Rzeczpospolitej Ludowej z 22 lipca 1952, Dz.U. $1952 \mathrm{nr} 33$ poz. 232, prawo.sejm.gov.pl/isap.nsf/download.xsp/ WDU19520330232/O/D19520232.pdf [dostęp: 31.03.2020].

19 W. Zamkowski, op. cit., s. 25.

20 Ibidem., s. 38.

21 Ibidem., s. 39.

22 Ibidem., s. 40.

23 Ibidem.

24 Ibidem. „Określenia lud, ludowy stosuje się głównie wtedy, gdy idzie o podkreślenie postępowych społeczno-ekonomicznych cech zbiorowości ludzkich czy poszczególnych instytucji, terminy naród, narodowy - symbolizują, akcentują rzeczywistą lub postulowaną jedność społeczeństwa”.

25 Ibidem., s. 41. 
dopiero doświadczenia walk społecznych, działalności politycznej i ideologicznej organizacji, aby ludziom pracy uświadomić ich wspólny interes. Działalność tego typu, jak wykazuje historia, prowadziła i prowadzi do powstawania frontów ludowych (narodowych). Opierając się na nich masy pracujące zdobyly lub przygotowują się do zdobycia władzy państwowej ${ }^{26}$.

Projekt teatru ludowego PRL w moim rozumieniu jest projektem teatru narodowego in spe, wpisującym się w politykę budowania nowej więzi społecznej a przyczynki jego powstania i ideologiczna misja zupełnie inne niż w przypadku teatrów ludowych pojawiających się w Polsce od połowy XIX w. Co, w tym przypadku, należałoby do jego podstawowych zadań? W myśl teorii Zamkowskiego - byłoby nim uświadamianie więzi łączącej lud pracujący, a tym samym wzmacnianie jego sprawczości i zdolności do budowania nowego państwa, w którym między narodem a ludem pracującym można by postawić znak równości. Byłoby to o tyle istotne z politycznego punktu widzenia, o ile w kolejnym zdaniu preambuły Konstytucji PRL mowa o "polskich masach narodowych”, a zatem podkreśla się narodowy charakter państwa („Polska Rzeczpospolita Ludowa nawiązuje do najszczytniejszych postępowych tradycji narodu Polskiego i urzeczywistnia idee wyzwoleńcze polskich mas pracujących"). Tym samym praca ludzi teatru stałaby się „społecznie użyteczna” w tym sensie, że byłaby służbą suwerenowi.

\section{W poszukiwaniu widza myślącego, który byłby partnerem do rozmowy ${ }^{27}$}

Obejmując dyrekcję Teatru Ludowego, Krystyna Skuszanka i Jerzy Krasowski sformułowali swój projekt następującymi słowami:

26 Ibidem., s. 36.

27 J. Ciosek, Teatr Józefa Szajny, „Dziennik Polski” 207, 76/30.03, www.e-teatr. $\mathrm{pl} / \mathrm{pl} /$ artykuly/37400,druk.html [dostęp: 31.03.2020]: „Nigdy nie chodziło mi w teatrze o banalną rozrywkę. Nie chciałem, by się moje przedstawienia podobały, bo podobać może się występ zespołu Mazowsze. Czekałem na widza myślącego, który byłby dla mnie partnerem w naszej rozmowie. Już w początkach mojej kariery mówiłem: Przestańmy w teatrze słuchać, a zacznijmy patrzeć, uczestniczyć. Bo sztuka jest ciałem, a nie słowem, jest zderzeniem słowa, plastyki i dźwięku, jest ruchem czasu, a nie statyką historyczną. Nie chcę, by rozmawiano ze mną osobno o teatrze, plastyce, poezji, dramacie, bo sztuka jest tworzeniem integralnych zjawisk. Stąd też moje zmagania ze sztuką nazwałem później TEATREM - to coś różnego niż teatr czy plastyka scenografa”. 
szukamy w teatrze tego, co uważamy za istotę ludowego dramatu (ludowość rozumiem przez podniesienie jej wartości do rangi powszechnej) - ostrego rysunku konfliktów, elementów tragizmu przy pełnej, heroicznej afirmacji życia w jego kontrastach, w jego gorącej temperaturze radości i bólu, jednoznacznej surowości w ocenach moralnych i jednolitej, uogólniającej poezji. Odrzucamy opisowość i dekoracyjność, szukamy tych środków teatralnego wyrazu, które podporządkować można nadrzędnej i metaforycznej funkcji dramatu. Żywym źródłem inspiracji są dla nas tradycje romantycznej polityki teatru. Pragniemy też, aby nowo powstający teatr stał się teatrem prawdziwie narodowym ${ }^{28}$.

Ambicje Krasowskich, którzy z Teatru Ludowego chcieli uczynić teatr prawdziwie narodowy, zdają się zatem zbieżne z misją teatru ludowego PRL w takim rozumieniu, jakie wyprowadziłam z rozważań Zamkowskiego nad ludem w rozumieniu Konstytucji z 1952 roku. Jednak wybory repertuarowe Skuszanki, zwłaszcza zamiłowanie do repertuaru romantycznego i Szekspira, przyciągały bardziej Krakowian niż robotników z Nowej Huty, podobnie zresztą jak nowatorskie podejście Szajny. Lud pracujący domagał się od dyrekcji lekkich komedii, fars i wodewili.

Skłonność do eksperymentów z formą stanowiła oś konfliktu z władzami, a w konsekwencji poskutkowała zmianą na stanowisku dyrektora teatru. W 1962 roku Skuszankę zastąpił Józef Szajna, który wspominał, że:

porady płynące z Warszawy, próby sterowania kulturą w Nowej Hucie okazywały się często mylne i opaczne. Nowe miasto potrzebowało nowych rozwiązań, a prekursorstwo i awangarda były na ustach wielu młodych środowisk twórczych, zarówno plastycznych, jak i wśród muzyków i poetów ${ }^{29}$.

Zmiana na stanowisku kierowniczym nie przełożyła się jednak zasadniczo na zmianę kierunku repertuaru, ponieważ podobnie jak Krasowscy, Szajna cenił sobie widza myślącego, z którym można by prowadzić dialog ${ }^{30}$. Projekt kulturalny, jaki zrodził się z tych wizji, w żaden sposób nie mógł stanowić odpowiedzi na wezwanie do budowania i umacniania „więzi łączącej lud pracujący”. Jego szersze omówienie znacznie przekraczałoby rozmiary niniejszego tekstu.

Komparatystyczne podejście do teatru ludowego PRL wymaga od badacza przede wszystkim zdefiniowania charakteru zbiorowości, jaką jego twórcy określali mianem "ludu” nie tyle ze względu na wieloznaczność samego pojęcia „ludu”, co na dodatkową trudność wynikającą z faktu, że określenie

28 K. Skuszanka, O artystyczne oblicze teatru, „Życie Literackie” 1955.

29 J. Józef, Moich jedenaście lat w Teatrze Ludowym, [w: 30 lat Teatru Ludowego w Krakowie - Nowej Hucie, M. Broniowska, J. Lenczowski (red.), Kraków 1988, s. 33.

30 J. Ciosek, op. cit. 
teatro popolare skłania, w sposób bardziej bezpośredni niż w języku polskim, do szukania powinowactw z projektem Vilara. Dookreślenie, w odniesieniu do Konstytucji PRL, terminu „lud pracujący” i przeciwstawienie go narodowi, otwiera przed badaczem szersze ramy interpretacyjne dynamiki, w jakiej kształtował się projekt kulturalny Teatru Ludowego Krasowskich i Szajny.

\section{Bibliografia}

Barba E., Ziemia popiotu i diamentów. Moje terminowanie w Polsce oraz 26 listów Jerzego Grotowskiego do Eugenia Barby, Wrocław 2001.

Ciosek J., Teatr Józefa Szajny, „Dziennik Polski” 2007, 76/30.03, www.e-teatr.pl/pl/artykuly/37400,druk.html [dostęp: 31.03.2020].

Domański D., Teatr noszę w sobie, „Gazeta Krakowska” 2005, 289, www.e-teatr.pl/pl/artykuly/19600,druk.html [dostęp: 31.03.2020].

Olkusz P., Wąsik M., (red.), Teatry dla masowej publiczności, Łódź 2017.

Skuszanka K., O artystyczne oblicze teatru, „Życie Literackie” 1955.

Skuszanka K., Teatr na straży młodości, „Dziennik Polski” 1955, nr 3569, s. 8.

Szajna J., Moich jedenaście lat w Teatrze Ludowym, [w: 30 lat Teatru Ludowego w Krakowie - Nowej Hucie, M. Broniowska, J. Lenczowski, (red.), Kraków 1988.

Trezzini L., Teatro in Polonia, Bologna 1962.

Zamkowski W., Pojęcie ludu pracującego w Konstytucji PRL, „Ruch Prawniczy, Ekonomiczny i Socjologiczny" 1965, 27 z. 2, s. 25-43.

\section{Netografia}

Konstytucja Polskiej Rzeczpospolitej Ludowej z 22 lipca 1952, Dz.U. 1952 nr 33 poz. 232, prawo.sejm.gov.pl/isap.nsf/download.xsp/WDU19520330232/O/D 19520232.pdf [dostęp: 31.03.2020].

LegońJ.,Jean Vilar, Encyklopedia Teatru Polskiego, www.encyklopediateatru.pl/osoby/52132/ jean-vilar [dostęp: 30.03.2020].

popolare, Treccani, www.treccani.it/vocabolario/popolare1/ [dostęp: 30.03.2020]; Grande Dizionario Italiano, Hoepli, www.grandidizionari.it/Dizionario_Italiano/parola/P/popolare_1.aspx?query=popolare+(1) [dostęp: 30.03.2020].

popolare, Grande Dizionario Italiano, Hoepli, www.grandidizionari.it/Dizionario_Italiano/ parola/P/popolare_1.aspx?query=popolare+(1) [dostęp: 30.03.2020].

Ratajczakowa D.: teatr $\overline{l u}$ dowy, Encyklopedia Teatru Polskiego,www.encyklopediateatru.pl/ hasla/163/teatr-ludowy [dostęp: 30.03.2020]. 